\title{
ANALYSIS OF REASONS FOR UNPLANNED STOPPAGES OF MACHINES IN THE EXAMPLE OF THE LONGWALL SHEARER
}

\author{
Kinga Stecuła, ${ }^{1}$ Jarosław Brodny, ${ }^{2}$ Dorota Palka ${ }^{3}$
}

\begin{abstract}
Production enterprises mainly focus on activities concerning tangible resources. In recent years, however, this focus has shifted increasingly towards intangible resources such as knowledge as a key resource. Knowledge plays a crucial role in building an enterprise's competitive advantage, including that of mining entities involved in coal extraction. This article presents results of research into the causes of unplanned stoppages in the operation of longwall shearers. An examination of the parameters of the longwall shearer operation reveals an oversight in recording the causes of many unplanned machinery stoppages. Using informatics tools, the authors determine the reasons for most stoppages. The knowledge gained in this research has practical significance in providing a basis for implementing actions to limit the number of stoppages and improve the effectiveness of the machinery.
\end{abstract}

UDC Classification: 622.2; DOI: http://dx.doi.org/10.12955/cbup.v5.1098

Keywords: unplanned stoppages, tacit knowledge, effectiveness, mining machines.

\section{Introduction}

Production companies mainly base their activities on tangible resources. Fixed assets, finances, and stores are essential elements for the industry to function and operate. In recent years, however, the role of intangible resources has increased. These resources are no longer perceived as additional elements of business and have become a key factor in achieving a competitive advantage for many organizations. The intangible resources consist of competencies, knowledge, relations, attitudes, opportunities, brands, and functional systems (Stankiewicz, 2005). In addition, these resources include internal knowledge about technology, employees' skills and procedures of behavior (Wernerfelt, 1984).

The effective use of intangible resources also concerns the mining industry. The optimization of production costs (Loska, 2013; Loska 2017) means that intangible resources can determine the competitive advantage in this industry. In recent years, the increasing trend among varying industrial companies regarding the importance of these resources has reached the mining industry. Mining companies have started to increasingly appreciate the competencies of their employees, whose knowledge, skills, involvement, and identification with the company are among its greatest elements and thus, its influential capital (Kaźmierczak, 2014).

The research results presented in this paper are a positive example of the application of knowledge in the mining industry. The authors, using informatics tools, have identified the causes of breaks during the operation of mining machinery. The paper focuses on determining the causes of the breaks in the operation of a longwall shearer. However, it should be noted that the methodology developed from this research will help determine the reasons for breaks in the operation of most mining machinery. This identification refers to unplanned breaks that have been registered by the industrial automation system. Past procedures allowed for the identification of only about $25 \%$ of the causes for such breaks. The developed and applied new system identified on average about $70 \%$ of the causes. Therefore, the results have a significant practical meaning. The knowledge gained regarding the reasons for the unplanned stoppages allows for specific actions to limit the number of breaks. This remedial action then increases the effectiveness of these machines and thus, the entire enterprise. The longwall shearer was chosen for this study because it is directly involved in excavating coal from rock mass. The breaks in its operation almost always result in further stoppages affecting the transporting machines and are associated with considerable economic losses.

\section{The System for Registration of the Reasons for the Breaks in the Machine Operation}

Studies into the effectiveness of using mining machines indicate that the availability and performance of the machines are unsatisfactory (Nakajima, 1988; Brodny et al., 2016; Stecuła \& Brodny, 2016).

\footnotetext{
${ }^{1}$ Faculty of Organization and Management, Silesian University of Technology, kinga.stecula@polsl.pl

${ }^{2}$ Faculty of Organization and Management, Silesian University of Technology, jaroslaw.brodny@polsl.pl

${ }^{3}$ Faculty of Organization and Management, Silesian University of Technology, dorota.palka@polsl.pl
} 
This scenario is especially the case with availability. The registration of the operating times of these machines shows that there are many unplanned breaks. At the same time, the system that registers the causes of these breaks contains only a small fraction. The remainder of these breaks are not registered, and their causes are unknown. It is assumed that these breaks are caused by the difficult conditions of the underground exploitation. However, without knowing the direct causes of the downtimes, it is impossible to optimize the machines' operation time. The low value of the availability indicator results in poor exploitation of the full potential of the mining machine.

The aim of this study is to improve the effectiveness of using mining machines by developing a system of semi-automatic registration of the causes of the breaks in the mining machinery's operation.

\section{Data and Methodology}

The study involved expert interviews with mine dispatchers who had knowledge of the reasons for most unplanned downtimes but were not necessarily motivated to use the required system to register causes because of the potential consequences of using such a system. The new system for registering causes was developed to ensure an effortless, convenient and, most importantly, anonymous approach to registering the reasons. It was designed so that the information reported by dispatchers regarding a specific event was encoded and accessible only to the operator with only the Director of the mine having access to this information by written request. With the acceptance of these conditions, an IT tool was developed in the form of a system for identifying the causes of stoppages in operating the mining machinery. The system was designed to disclose the tacit knowledge of the dispatchers and for monitoring the increased use of the machinery as well as the general situation at the mine. Converting tacit knowledge into explicit knowledge was a key objective of the developed system.

The system of the registration of the causes of the breaks in the machine operation was integrated with the dispatcher's system of the mine to allow for the use of existing infrastructure and to avoid generating additional costs. The system was developed so that the registration module intuitively registers the cause of equipment failure from reasons automatically proposed by the system, based on the most frequent causes of stoppages for that particular machine. In the case of a new event, the dispatcher manually adds a brief description of the event, which is then entered into the system after further analysis. This means that the system is open and its database is constantly updated. Figure 1 shows the online form for registering failure of equipment.

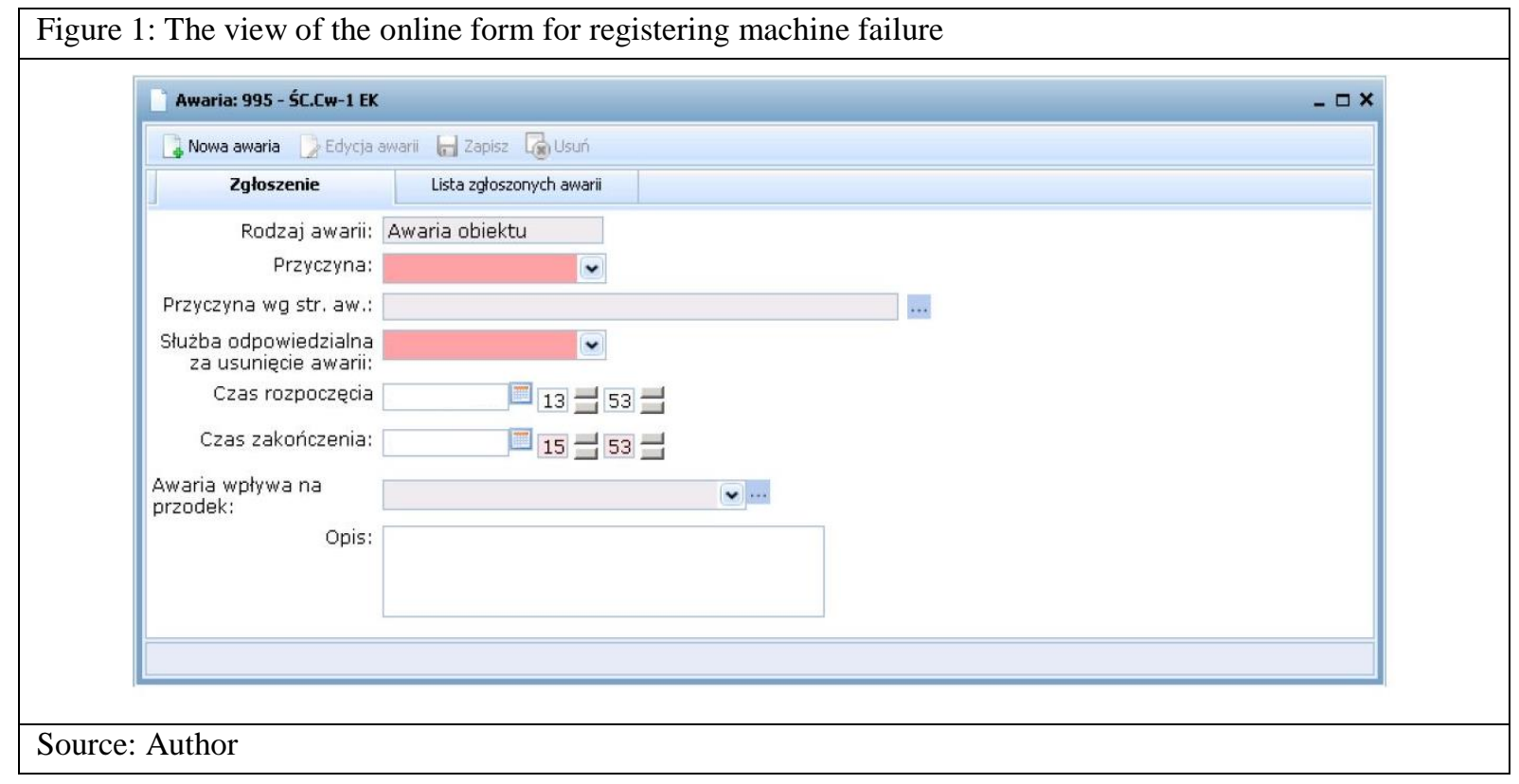

The Analysis of the Reasons for the Breaks in the Longwall Shearer's Operation

Registering the causes for stoppages in the longwall shearer operation took place over one week (15 operational shifts). The duration of specific breaks was determined from data of the industrial automation system. All breaks lasting more than 30 seconds were assessed. It was assumed that 
downtimes less than 30 seconds would be difficult to identify, and thus, results for this group would have low credibility.

The developed system was also used to determine the types of causes for breaks in the longwall shearer operation. In this case, breaks were classified into five groups: mechanical, electrical, hydraulic, mining, and organizational causes. Interviews with experts and dispatchers provided the means of classifying the causes by the organizational group.

\section{Results and Discussion}

Figure 2 shows the time structure of the breaks recorded by the automation system during the operation of the longwall shearer for 15 work shifts and the number of breaks with identified causes compared to the total. Table 1 summarizes total durations of registered breaks and those with identified reasons. Additionally, the percentage of durations of breaks with an identified cause relative to the total durations is shown for each interval.

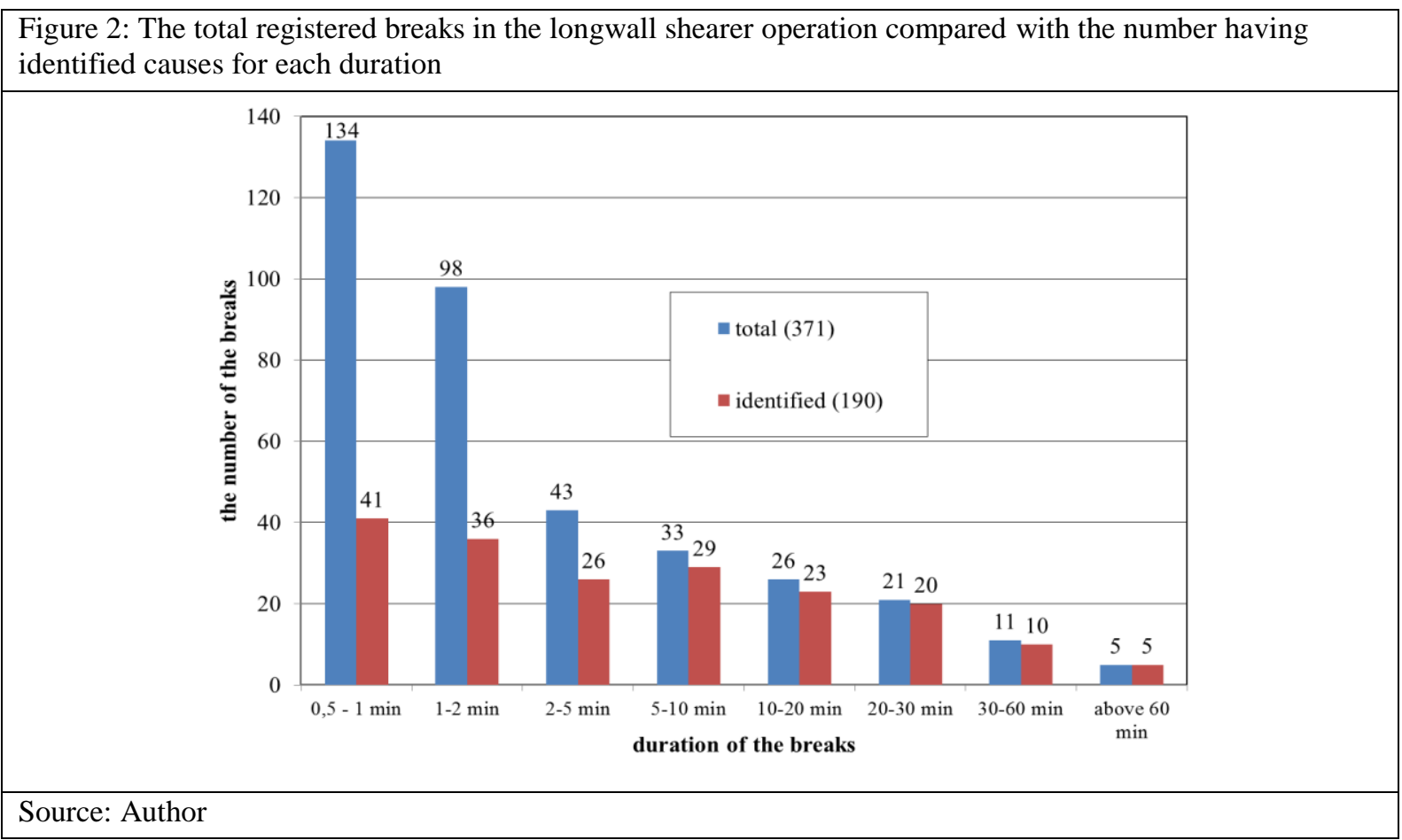

Figure 3 shows the results for before and after implementing the identification system where stoppage reasons were found for 190 of the 371 registered breaks (data from Figure 2) with a quantitative efficiency of the identification approximately $51.20 \%$. The 'after' result was understated by a low level of determination for the short breaks. For the intervals lasting from 0.5-1.0 min, the efficiency was $30.6 \%$. This low result was due to the shortness of the duration, which meant the dispatcher was not always able to register the event in the system. However, the reporting of breaks was higher in events with longer duration.

The study identified stoppage reasons for $83.94 \%$ of the total breaks registered for the longwall shearer during the study period (Table 1). This high percentage is attributed to the heightened efficiency, especially in determining the causes of the lengthy breaks. In the case of breaks lasting more than 10 minutes, this efficiency was above $93,65 \%$, which is noteworthy.

Figure 3 compares the results of before and after implementing the new system to demonstrate the efficiency of the developed tool. The registration time was 15 operational shifts with different periods of the longwall shearer operation compared. Nevertheless, a significant change in the number of the identified causes of the breaks was observed. Thus, the application of the developed system to identify causes of breaks in the longwall shearer operation appears to improve the efficiency of the identification considerably. 


\begin{tabular}{|c|c|c|c|c|}
\hline & Break & Registered & Breaks & ntified \\
\hline & $(\min )$ & $(\min )$ & $(\min )$ & $\%$ \\
\hline & $0.5-1.0$ & 89 & 31 & 34.83 \\
\hline & $1.0-2.0$ & 127 & 50 & 39.37 \\
\hline & $2.0-5.0$ & 129 & 62 & 48.06 \\
\hline & $5.0-10.0$ & 231 & 174 & 75.32 \\
\hline & $10.0-20.0$ & 340 & 296 & 87.06 \\
\hline & $20.0-30.0$ & 526 & 503 & 95.63 \\
\hline & $30.0-60.0$ & 485 & 443 & 91.34 \\
\hline & above 60.0 & 365 & 365 & 100.00 \\
\hline & Total & 2292 & 1924 & 83.94 \\
\hline
\end{tabular}
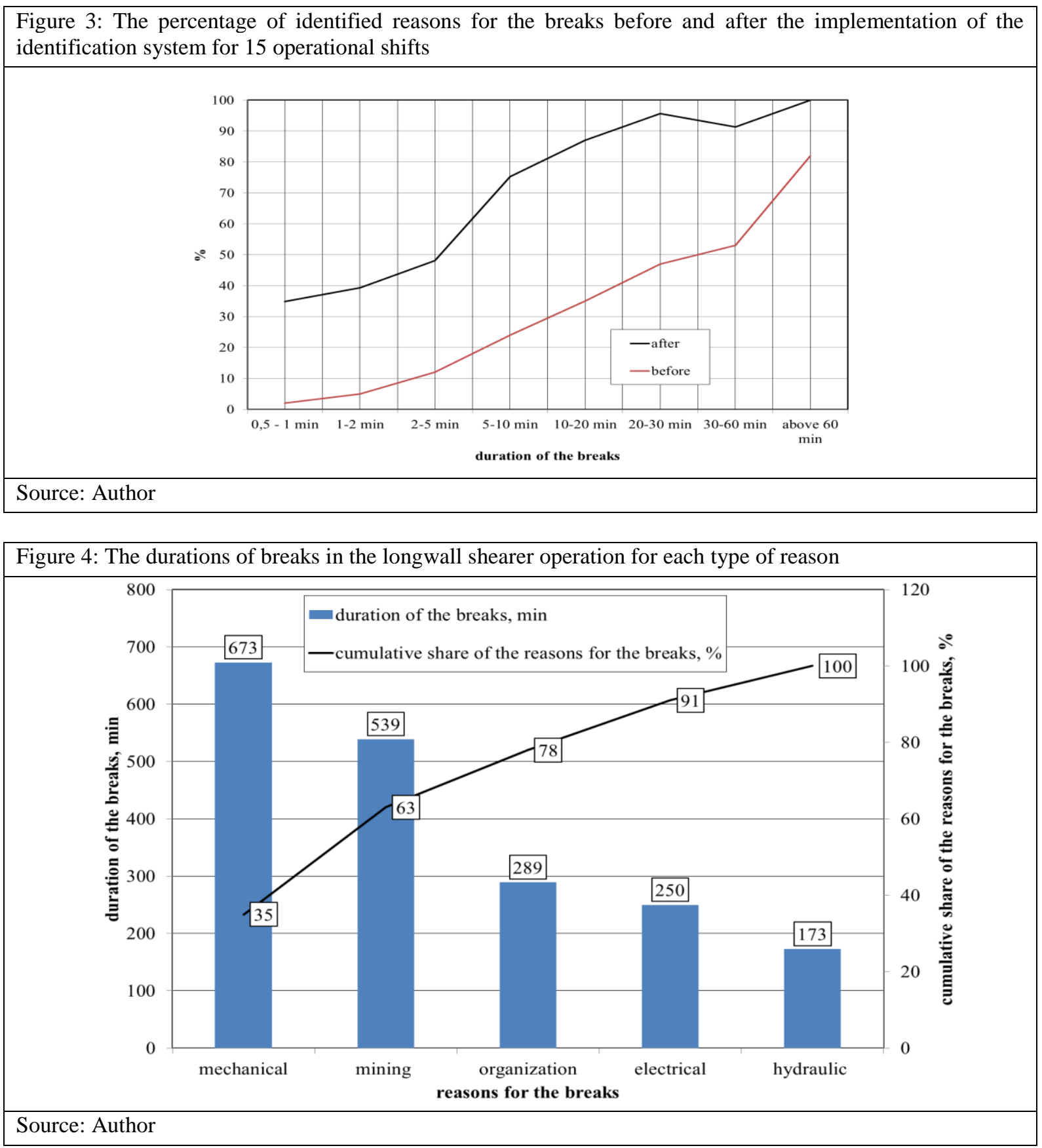
Figure 4 shows five groups of reasons for breaks in the longwall shearer operation according to the total durations of breaks (in minutes) and their cumulative percentage. The results reveal that the main causes of the breaks are mechanical and mining (Figure 4). Organizational, electrical, and hydraulic reasons play a smaller role. Information about the types of causes for the breaks has practical implications as it can be used to optimize the operation of individual maintenance services.

\section{Conclusion}

The issue presented in the article has practical significance. Knowledge about the reasons for recorded breaks in machinery operation can lead to actions to increase the effectiveness of operations. The results of the study indicate the low efficiency of the previous way for registering causes for operational failures and downtimes. The implementation of a new system, based on an objective registration of the duration of the breaks, and information about the causes provide a way to identify most reasons. The tacit knowledge of the dispatchers gained through expert interviews combined with the developed IT tool led to a solution to a significant problem related to the machine exploitation in the mining company. The information gained from this study is exceedingly valuable to the management of a mine as well as the producers of the machines, as it identifies the components of the machines that generate the greatest problems for the users. The results revealed that many small breaks occur in the operation of the longwall shearer. Further research is recommended to help identify the specific causes of these breaks. Although the breaks have little effect on the longwall shearer availability, they potentially create serious technical issues. Frequently, such short breaks require unproductive engine restarts of the longwall shearer. The data presented in this article are part of a larger set that includes the monitoring of all machinery in the mechanized longwall system. It is recommended that the results of this research be used as a basis for reducing downtimes, and subsequently, improving the effectiveness of mine machinery including the longwall shearer.

\section{Acknowledgements}

This article is the result of the research project No. PBS3/B6/25/2015 "Application of the Overall Equipment Effectiveness method to improve the effectiveness of the mechanized longwall systems' operation in the coal exploitation process" realized in 2015-2017, financed by NCBiR (National Centre for Research and Development).

\section{References}

Brodny, J., Stecuła, K., Tutak, M. (2016). Application of the TPM strategy to analyze the effectiveness of using a set of mining machines, Proceedings of 16th International Multidisciplinary Scientific GeoConferences SGEM 2016, Book 1, Vol. II, Albena Bulgaria, 65-72. DOI: 10.5593/sgem2016B12/S03.009.

Kaźmierczak, J. (2014). Uwagi na temat gospodarowania danymi, informacją i wiedzą w zadaniach z obszaru inżynierii produkcji. Remarks on managing data, information and knowledge in tasks of production engineering, Systems Supporting Production Engineering, 2 (8), 88-100.

Loska, A. (2013). Exploitation assessment of selected technical objects using taxonomic methods. Eksploatacja i Niezawodność - Maintenance and Reliability, 15 (1), 1-8.

Loska, A. (2017). Scenario modeling exploitation decision-making process in technical network systems. Eksploatacja i Niezawodnosc - Maintenance and Reliability, 19 (2), 268-278.

Nakajima, S. (1988). Introduction to TPM. Total Productive Maintenance. Productivity Press, Portland Oregon.

Stankiewicz M. J., (2005). Konkurencyjność przedsiębiorstwa. Budowanie konkurencyjności przedsiębiorstwa w warunkach globalizacji, Wydawnictwo TNOiK „Dom Organizatora”, Toruń.

Stecuła, K., Brodny, J. (2016). Application of the OEE model to analyze the availability of the mining armored face conveyor, Proceedings of 16th International Multidisciplinary Scientific GeoConferences SGEM 2016, Book 1, Vol. II, Albena Bulgaria, 57-64. DOI: 10.5593/sgem2016B12/S03.008.

Wernerfelt, B. (1984). A resource-based view of the firm, „Strategic Management Journal”, Vol. 5, Nr 2, s. 171-180. 